\title{
ДОСЛІДЖЕННЯ ЖИРНОКИСЛОТНОГО СКЛАДУ ДЕЯКИХ РОСЛИН РОДИНИ АЙСТРОВІ (ASTERACEAE)
}

Вступ. Останнім часом велику увагу приділяють дослідженню ліпофрільних комплексів лікарських рослин, складовою частиною яких є жирні кислоти, що відіграють важливу роль у життєдіяльності організму людини. Рослини родини айстрові (Asteraceae) - якон (Smallanthus sonchifolius (Poepp. and Endl.) H. Robinson), стевія медоносна (Stevia rebaudiana (Bertoni) Hemsley) і котячі лапки дводомні (Antennaria dioica (L.) Gaertn.) - містять комплекс біологічно активних речовин, серед яких значне місце відводять ліпофільним компонентам (жирним кислотам, каротиноїдам, хлорофрілам тощо).

У джерелах наукової літератури недостатньо інформації про жирнокислотний склад досліджуваних видів, тому метою наших досліджень було вивчити ліпофрільні фрракції листків стевії медоносної, кореневих бульб і листків якона, трави котячих лапок дводомних та визначити вміст жирних кислот у їх складі.

Методи дослідження. Ліпофрільні фрракції досліджуваних видів лікарської рослинної сировини одержували шляхом вичерпного екстрагування сировини хлороформом в апараті Сокслета. Якісний склад та кількісний вміст жирних кислот у досліджуваній лікарській рослинній сировині визначали методом газорідинної хромато-мас-спектрометрії метилових естерів жирних кислот на газовій хромато-мас-спектрометричній системі Agilent 6890N/5973inert (Agilent Technologies, США). Ідентифрікацію метилових естерів жирних кислот досліджуваної суміші проводили шляхом порівняння часу утримування стандартної суміші метилових естерів жирних кислот (Supelco, CША). Використовували бібліотеку мас-спектрів NIST 02.

Результати й обговорення. Ліпофрільна фрракція, виділена з кореневих бульб якона, - густа масляниста однорідна маса буро-коричневого кольору з приємним специфрічним запахом, не розчиняється у воді та етанолі, добре розчиняється у хлорофрормі. Ліпофрільні фрракції листків темно-зеленого кольору; трави котячих лапок дводомних - світло-зеленого; за іншими фрізичними показниками одержані субстанції не відрізнялись. Встановлено, що вихід ліпофрільних речовин з листків якона та листків стевії медоносної був майже однаковий - $(9,55 \pm 0,09)$ i $(9,05 \pm 0,07) \%$, з кореневих бульб якона - у 2,4 і 2,2 раза менший, ніж $з$ листків відповідно. Вихід ліпофрільних фрракцій з трави котячих лапок дводомних становив $(8,25 \pm 0,09) \%$. У ліпофрільних екстрактах листків якона та трави котячих лапок дводомних виявлено по 9 жирних кислот, 23 яких є поліненасиченими - лінолева і ліноленова; в ліпоорільному екстракті листків стевії медоносної - 8 жирних кислот, з яких в найбільшій кількості представлена ліноленова кислота. У ліпофільних екстрактах листків стевії медоносної та трави котячих лапок дводомних міститься насичена пальмітинова кислота. Вміст ненасичених жирних кислот у досліджуваних ліпофрільних екстрактах переважав над вмістом насичених. Їх співвідношення у листках якона становило 55,35:8,63; у листках стевії медоносної- 3,04:1,87; у траві котячих лапок дводомних - 29,09:20,26 відповідно. У ліпофрільному екстракті кореневих бульб якона ідентифріковано лише лінолеву і ліноленову кислоти.

Висновки. Уперше методом газорідинної хромато-мас-спектрометрії визначено жирнокислотний склад ліпофрільних фрракцій листків стевії медоносної, кореневих бульб і листків якона та трави котячих лапок дводомних. У листках стевії медоносної і якона та траві котячих лапок дводомних ненасичені жирні кислоти переважають над насиченими. У досліджуваних об'єктах домінують поліненасичені жирні кислоmи - лінолева і ліноленова. У кореневих бульбах якона ідентифіковано лише лінолеву і ліноленову кислоти.

КЛЮЧОВІ СЛОВА: стевія медоносна; якон; котячі лапки дводомні; ліпофрільні комплекси; жирні кислоти.

ВСТУП. Останнім часом велику увагу приділяють дослідженню ліпофрільних комплексів лікарських рослин, складовою частиною яких $€$ жирні кислоти, що відіграють важливу роль у життєдіяльності організму людини. Вони є обов'язковим компонентом біологічних мембран,

(ㄱ С. М. Марчишин, Н. А. Гудзь, Р. Ю. Басараба, Т. Я. Ярошенко, 2018. впливають на метаболізм стероїдних сполук, беруть участь у біосинтезі жирів [1]. Незамінні жирні кислоти (вітамін F) запобігають розвитку атеросклерозу, мають антитромботичний, кардіопротекторний, антиаритмічний ефекти, є попередниками біосинтезу простагландинів, які, у свою чергу, регулюють артеріальний тиск [1, 2]. Нестача вітаміну F викликає дерматити, 
зменшує коагулюючі властивості крові й регулює артеріальний тиск [3, 4], сприяє виникненню онкологічних захворювань [5].

Рослини родини айстрові (Asteraceae) - якон (Smallanthus sonchifolius (Poepp. and Endl.) H. Robinson), стевія медоносна (Stevia rebaudiana (Bertoni) Hemsley) і котячі лапки дводомні (Antennaria dioica (L.) Gaertn.) - містять комплекс біологічно активних речовин [6-10], серед яких значне місце відводять ліпофрільним компонентам (жирним кислотам, каротиноїдам, хлорофрілам тощо).

У джерелах наукової літератури недостатньо інорормації про жирнокислотний склад досліджуваних видів, тому метою наших досліджень було вивчити ліпофрільні фрракції листків стевії медоносної, кореневих бульб і листків якона, трави котячих лапок дводомних та визначити вміст жирних кислот у їх складі.

МЕТОДИ ДОСЛІДЖЕННЯ. Ліпофрільні фрракції досліджуваних видів лікарської рослинної сировини (ЛРС) одержували шляхом вичерпного екстрагування сировини хлороформом в апараті Сокслета [11, 12].

Якісний склад та кількісний вміст жирних кислот у досліджуваній ЛРС визначали методом газорідинної хромато-мас-спектрометрії (ГХ/МС) метилових естерів жирних кислот на газовій хромато-мас-спектрометричній системі Agilent 6890N/5973inert (Agilent Technologies, США). Використовували колонку капілярну HР-5ms (30 м $\times 0,25$ мм $\times 0,25$ мкм, Agilent Technologies, США). Температура випарника $-250^{\circ} \mathrm{C}$, температура інтерсейсу $-280^{\circ} \mathrm{C}$. Поділ проводили в режимі програмування температури - початкову температуру $60^{\circ} \mathrm{C}$ витримували протягом 4 хв, з градієнтом $4{ }^{\circ} \mathrm{C} /$ хв піднімали до $250^{\circ} \mathrm{C}$, витримували 6 хв, 3 градієнтом $20^{\circ} \mathrm{C}$ піднімали до $300{ }^{\circ} \mathrm{C}$, витримували 5 хв.

Підготовка проби для аналізу: ЛРС подрібнювали до порошкоподібного стану в скляній ступці. Наважку препарату 500 мг (точна наважка) поміщали в скляну віалу і додавали реакційну суміш (метанол $\mathrm{P}$ - толуол - кислота сульфратна $\mathrm{P}(44: 20: 2))$ по 3,3 мл на пробу та розчин внутрішнього стандарту в гептані в кількості 1,7 мл. Досліджувану пробу витримували при температурі $80^{\circ} \mathrm{C}$ протягом 2 год, охолоджували до кімнатної температури, центрисругували 10 хв при 5000 об./хв. Відбирали 0,5 мл верхньої гексанової фази, що містить метилові естери жирних кислот.

Пробу об'ємом 1 мкл вводили в режимі поділу потоку 1:20. Детектування виконували в режимі SCAN у діапазоні (38-400). Швидкість потоку газу-носія через колонку - 1,0 мл/хв.
Ідентифікацію метилових естерів жирних кислот досліджуваної суміші проводили шляхом порівняння часу утримування стандартної суміші метилових естерів жирних кислот (Supelco, США). Використовували бібліотеку мас-спектрів NIST 02.

Кількісний аналіз проводили шляхом додавання розчину внутрішнього стандарту в досліджувані проби. Як внутрішній стандарт використовували розчин кислоти ундеканової.

Масу жирної кислоти на 1 кг сировини в міліграмах розраховували за формулою:

$$
\mathrm{X}=\frac{\mathrm{Sx} \cdot \mathrm{Mвн.ст.} \cdot 1000}{\text { Sвн.ст. } \mathrm{m}},
$$

де Sx - площа піку жирної кислоти;

Мвн.ст. - маса внутрішнього стандарту на пробу;

Sвн.ст. - площа піку внутрішнього стандарту; m - наважка сировини [13, 14].

РЕЗУЛЬТАТИ Й ОБГОВОРЕННЯ. РеЗУЛЬТаТИ виходу ліпофрільної срракції наведено в таблиці 1.

Ліпофільна фрракція, виділена з кореневих бульб якона, - густа масляниста однорідна маса буро-коричневого кольору з приємним специфрічним запахом, не розчиняється у воді та спирті, добре розчиняється у хлороформі. Ліпофрільні фрракції листків темно-зеленого кольору; трави котячих лапок дводомних - світло-зеленого; за іншими фрізичними показниками одержані субстанції не відрізнялись. Встановлено, що вихід ліпофрільних речовин 3 листків якона та листків стевії медоносної був майже однаковий $(9,55 \pm 0,09)$ і $(9,05 \pm 0,07) \%, 3$ кореневих бульб якона - у 2,4 і 2,2 раза менший, ніж 3 листків відповідно. Вихід ліпофрільних фрракцій з трави котячих лапокдводомних становив $(8,25 \pm 0,09) \%$.

У досліджуваних видах ЛРС встановлено наявність насичених та ненасичених жирних кислот (табл. 2, рис. 1-3).

У результаті досліджень у ліпосрільних екстрактах листків якона та трави котячих лапок дводомних виявлено по 9 жирних кислот, 2 з яких є поліненасиченими - лінолева (16,39 і 14,59 мг/кг) та ліноленова (36,30 і 14,50 мг/кг) відповідно; в ліпофільному екстракті листків стевії медоносної-8 жирних кислот, з яких у найбільшій кількості представ-

Таблиця 1 - Кількісний вміст ліпофрільних речовин у кореневих бульбах і листках якона, листках стевії медоносної та траві котячих лапок дводомних $(\mathrm{n}=5)$

\begin{tabular}{|l|c|}
\hline \multicolumn{1}{|c|}{ Сировина } & Кількісний вміст, \% \\
\hline Листки якона & $9,55 \pm 0,09$ \\
\hline Кореневі бульби якона & $4,06 \pm 0,06$ \\
\hline Листки стевії медоносної & $9,05 \pm 0,07$ \\
\hline $\begin{array}{l}\text { Трава котячих лапок } \\
\text { дводомних }\end{array}$ & $8,25 \pm 0,09$ \\
\hline
\end{tabular}


Таблиця 2 - Якісний склад та кількісний вміст жирних кислот у листках якона і стевії медоносної та траві котячих лапок дводомних (метод ГХ/МС)

\begin{tabular}{|c|c|c|c|c|c|c|c|c|c|}
\hline \multirow[b]{2}{*}{ Назва кислоти } & \multirow[b]{2}{*}{ RT } & \multicolumn{2}{|c|}{ Вміст у мг/кг } & \multirow[b]{2}{*}{ RT } & \multicolumn{2}{|c|}{ Вміст у мг/кг } & \multirow[b]{2}{*}{ RT } & \multicolumn{2}{|c|}{ "Вміст у мг/кг } \\
\hline & & $\begin{array}{c}\text { листки } \\
\text { якона }\end{array}$ & $\begin{array}{c}\mathrm{MC}, \\
\%\end{array}$ & & $\begin{array}{c}\text { листки } \\
\text { стевії } \\
\text { медоносної }\end{array}$ & $\begin{array}{c}\text { MC, } \\
\%\end{array}$ & & $\begin{array}{c}\text { трава } \\
\text { котячих } \\
\text { лапок } \\
\text { дводомних } \\
\end{array}$ & $\begin{array}{c}\mathrm{MC}, \\
\%\end{array}$ \\
\hline Лауринова С12:0 & 25,800 & 0,61 & 70 & - & - & - & 26,272 & 0,38 & 96 \\
\hline Міристинова С14:0 & - & - & - & 34,529 & 0,03 & 98 & - & - & - \\
\hline Пальтоолеїнова* C16:1n9 & 36,485 & 2,66 & 58 & 39,475 & 0,12 & 86 & - & - & - \\
\hline Пальмітинова С16:0 & - & - & - & 39,591 & 1,65 & 98 & 37,051 & 14,72 & 98 \\
\hline Маргаринова 17:0 & - & - & - & - & - & - & 39,439 & 0,27 & 93 \\
\hline Лінолева* C18:2n9,12 & 40,506 & 16,39 & 99 & 43,483 & 0,98 & 99 & 40,992 & 14,59 & 99 \\
\hline Ліноленова* C18:3n9,12,15 & 40,662 & 36,30 & 90 & 43,648 & 2,06 & 98 & 41,135 & 14,50 & 99 \\
\hline Стеаринова С18:0 & 41,247 & 3,73 & 98 & 44,166 & 0,11 & 99 & 41,724 & 2,61 & 98 \\
\hline Арахінова C20:0 & 45,541 & 0,73 & 99 & 48,393 & 0,03 & 99 & 46,027 & 0,99 & 99 \\
\hline Бегенова С23:0 & 49,513 & 2,17 & 98 & 52,334 & 0,05 & 98 & 49,999 & 0,87 & 99 \\
\hline Лігноцеринова С24:0 & 53,392 & 1,39 & 98 & - & - & - & 54,021 & 0,42 & 89 \\
\hline
\end{tabular}

Примітки:

1. * - жирні ненасичені кислоти.

2. МС - відсоток збігу.

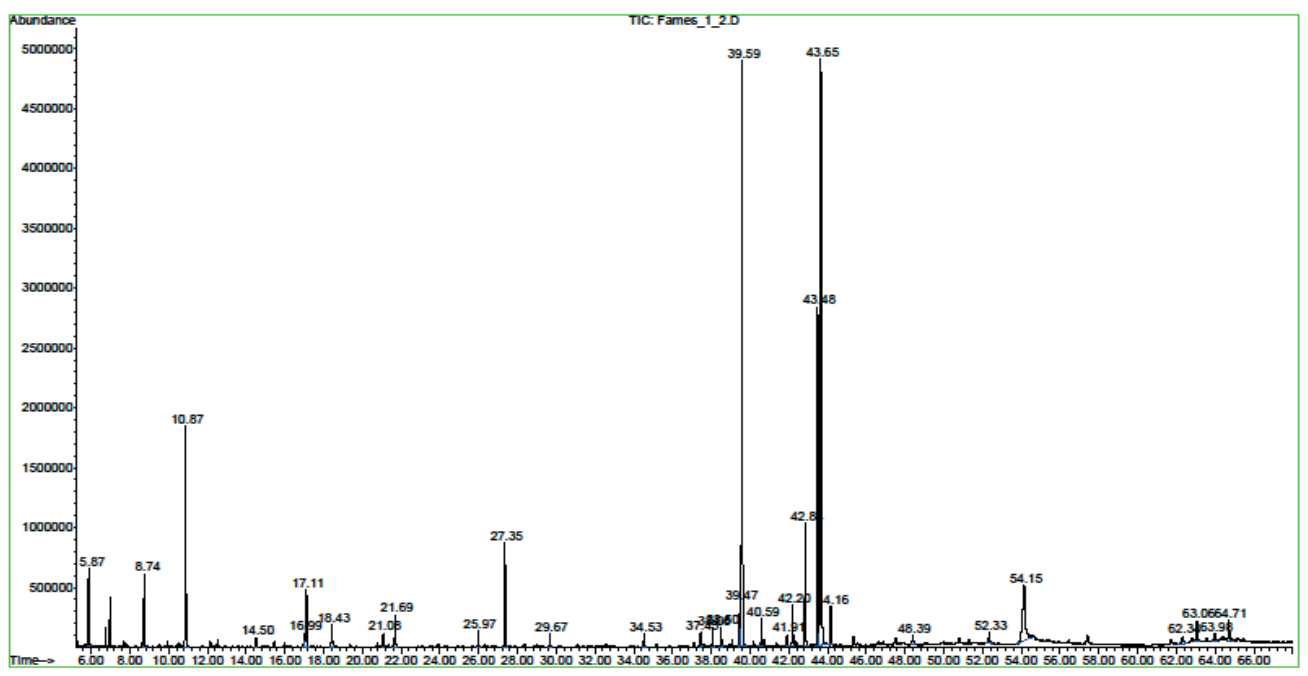

Рис. 1. Хроматограма ГХ-МС-аналізу метилових естерів жирних кислот листків стевії медоносної.

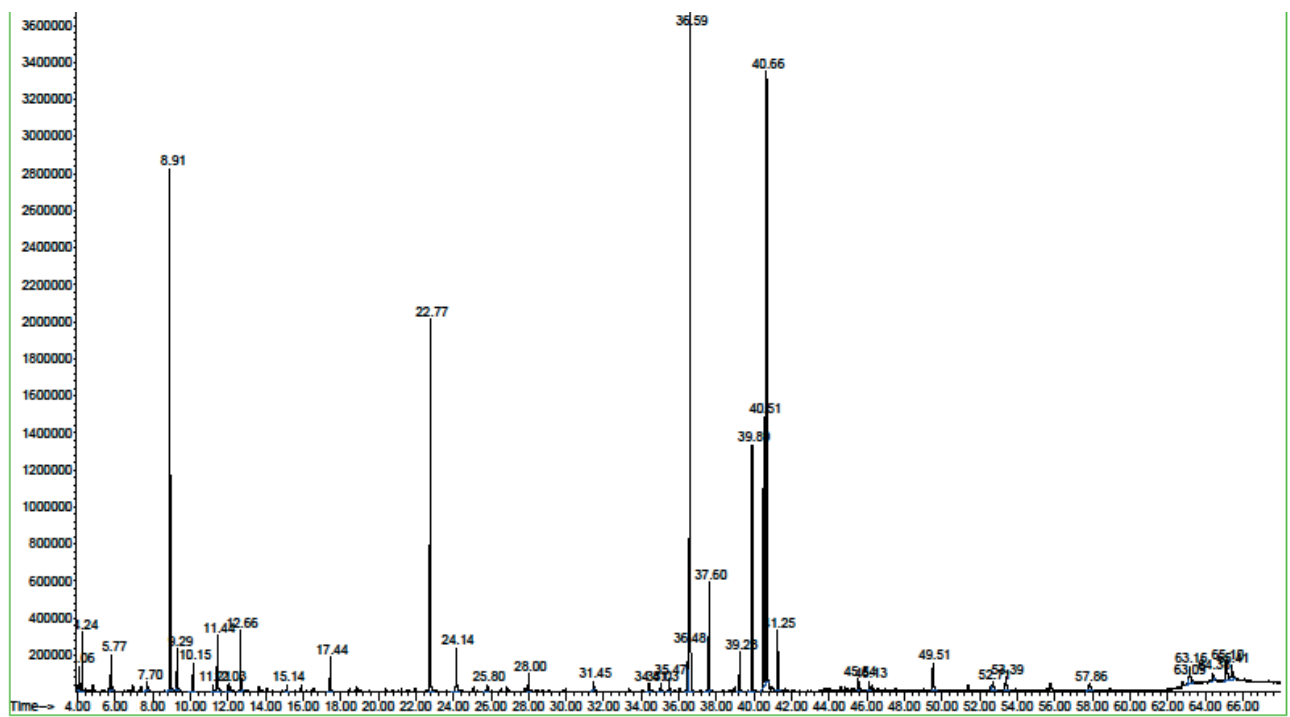

Рис. 2. Хроматограма ГХ-МС-аналізу метилових естерів листків якона. 


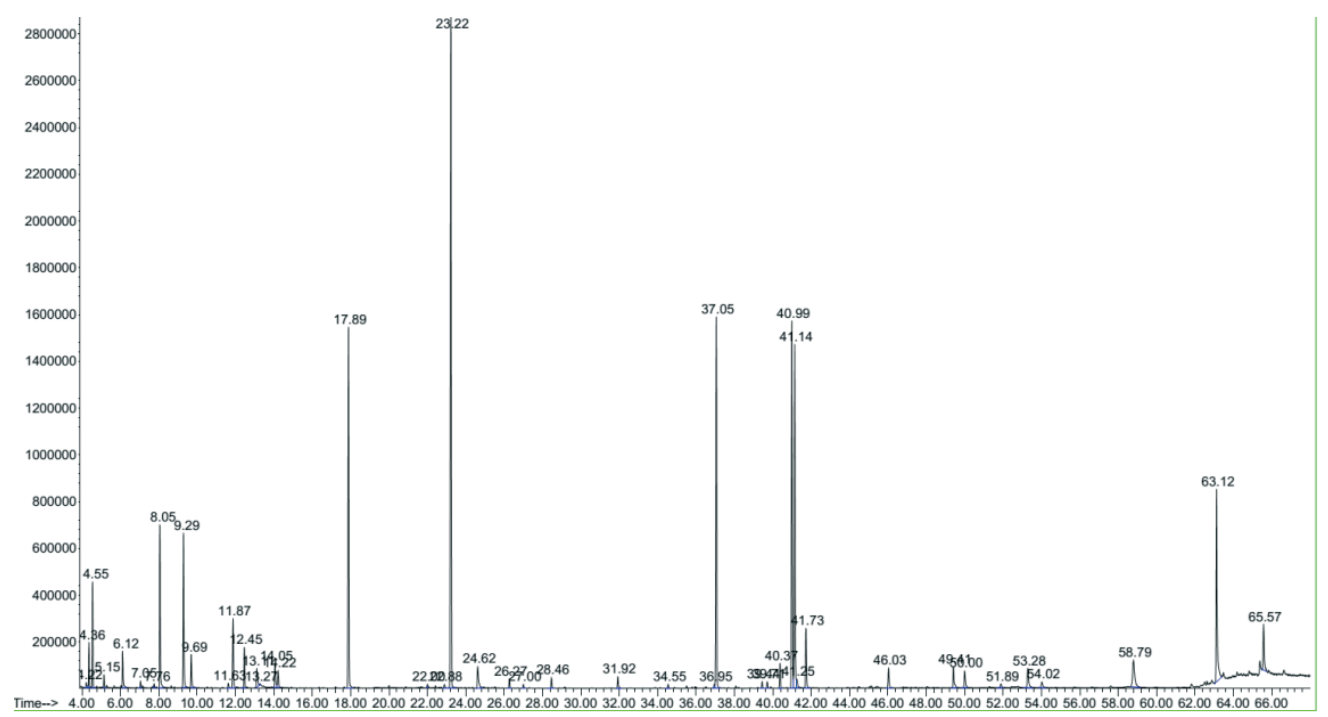

Рис. 3. Хроматограма ГХ-МС-аналізу метилових естерів трави котячих лапок дводомних.

лена ліноленова кислота (2,06 мг/кг) (табл. 2). Відомо, що ліноленова кислота, яка належить до омега-3 жирних кислот, проявляє гіпотензивну, протизапальну, імуномоделюючу, протипухлинну дію [15]. Недостатнє надходження есенціальних жирних кислот з їжею зумовлює порушення ліпідного обміну, виникнення атеросклерозу та інших серцево-судинних захворювань [16-19].

У ліпофрільних екстрактах листків стевії медоносної та трави котячих лапок дводомних міститься насичена пальмітинова кислота (1,65 \% і 14,72 мг/кг відповідно), яка, згідно з даними літератури, потрібна в організмі людини для утворення власного колагену, еластину та гіалуронової кислоти [15]. У листках якона і траві котячих лапок дводомних виявлено незначну кількість насичених лауринової і лігноцеринової кислот.

Встановлено, що вміст ненасичених жирних кислот у досліджуваних ліпофрільних екстрактах переважав над вмістом насичених. Їх співвідно- шення у листках якона становило 55,35:8,63; у листках стевії медоносної - 3,04:1,87; у траві котячих лапок дводомних -29,09:20,26 відповідно.

У ліпофрільному екстракті кореневих бульб якона ідентифіковано лінолеву і ліноленову кислоти, вміст яких становив 10,33 та 10,01 мг/кг відповідно.

ВИСНОВКИ. 1. Уперше методом газорідинної хромато-мас-спектрометрії визначено жирнокислотний склад ліпофрільних фрракцій листків стевії медоносної, кореневих бульб і листків якона та трави котячих лапок дводомних.

2. У листках стевії медоносної і якона та траві котячих лапок дводомних ненасичені жирні кислоти переважають над насиченими. У досліджуваних об'єктах домінують поліненасичені жирні кислоти - лінолева і ліноленова.

3. У кореневих бульбах якона ідентифріковано лінолеву і ліноленову кислоти.

\section{СПИСОК ЛІТЕРАТУРИ}

1.Челін Н. В. Жирнокислотний склад любистку лікарського (Levisticum officinale Koch.) / Н. В. Челін, C. М. Марчишин // Укр. журн. клініч. та лаб. медицини. -2011 . - № 1. - С. 33-36.

2. Луканюк М. І. Жирнокислотний склад листків деяких видів рослин родини Липові / М.І.Луканюк, С. М. Марчишин // Укр. біофармац. журн. - 2012. № 1-2 (18-19). - С. 62-66.

3. Визначення видового походження рослинних олій / В. А. Параніч, А. О. Дорошенко, О. Д. Рошаль, А. В. Параніч // Фармац. журн. -2000. - № 5. - С. 86-90.
4. Липиды семян Oenothera с различных мест произрастания. Сообщение I / С. Г. Юнусова, М. С. Юнусов, А. Р. Каримова [и др.] // Химия природных соединений. - 2007. - № 5. - С. 430-433.

5. Analysis of the fatty acids from Periploca sepium by GC-MS and GC-FID / Ling Tong, Lei Zhang, Yu. Shuanghui [et al.] // Asian Journal of Traditional Medicines. 2007. - 2 (3). - P. 110-114.

6. Гудзь Н. Фітохімічне дослідження якону / Н. Гудзь, T. Атаманчук // XIX Міжнар. мед. конгр. студентів і молодих вчених, присвячений пам'яті ректора чле- 
на-кореспондента НАМН України, профресора Леоніда Якимовича Ковальчука : матеріали конгр. (Тернопіль, 27-29 квіт. 2015 р.). - Тернопіль : ТДМУ, 2015. - С. 345 .

7. Марчишин С. М. Вміст амінокислот у траві котячих лапок дводомних (Antennaria dioica (L.) Gaertn.) / С. М. Марчишин, Р. Ю. Басараба // Теоретичні та практичні аспекти дослідження лікарських рослин : матеріали II Міжнар. наук.-практ. internetконор. (Харків, 21-23 берез. 2016 р.) / редкол. Т. М. Гонтова, А. О. Мінаєва, Н. І. Ільїнська. - Х. : НФаУ, 2016. - С. 159.

8. Марчишин С. М. Дослідження фрруктанів якона (POLYMNIA SONCHIFOLIUS POEPP. \& ENDL.) / С. М. Марчишин, Н. А. Гудзь, Л. Т. Міщенко // Фітотерапія. Часопис. - 2017. - № 3. - С. 58-63.

9. Analysis of phenolic compounds from Polymnia sonchifolia Poepp. et Endl. leaves by HPLC-method / S. Marchyshyn, N. Hudz, I. Dakhym [et al.] // The Pharma Innovation Journal. - 2017. - No. 6 (7). - P. 980-983.

10. Investigation of phenolic compounds of Antennaria dioica (L.) Gaertn. Herb / S. Marchyshyn, R. Basaraba, T. Berdey // The Pharma Innovation Journal. 2017. - No. 6 (8). - P. 09-11.

11. Бурлака І. С. Дослідження ліпофрільних фрракцій трави куничника звичайного та щучника дернистого / І. С. Бурлака, В. С. Кисличенко // Укр. мед. альм. - 2011. - 14, № 2. - С. 38-39.

12. Михалюк О. Б. Дослідження ліпосрільної фрракції листків і плодів лимонника китайського / О. Б. Михалюк // Укр. біофрармац. журн. - 2013. - № 5. C. $45-49$.

\section{REFERENCES}

1. Chelin, N.V., \& Marchyshyn, S.M. (2011). Zhyrnokyslotnyi sklad liubystku likarskoho (Levisticum officinale Koch.) [Fatty acid composition of medicinal feline (Levisticum officinale Koch.)]. Ukrainskyi zhurnal klinichnoi ta laboratornoi medytsyny - Ukrainian Journal of Clinical and Laboratory Medicine, 1, 33-36 [in Ukrainian].

2. Lukaniuk, M.I., \& Marchyshyn, S.M. (2012). Zhyrnokyslotnyi sklad lystkiv deiakykh vydiv roslyn rodyny Lypovi [Fatty acid composition of leaves of some species of plants of the lindenfamily]. Ukrainskyibiofarmatsevtychnyi zhurnal - Ukrainian Biopharmaceutical Journal, 1-2 (1819), 62-66 [in Ukrainian].

3. Paranich, V.A., Doroshenko, A.O., Roshal, O.D., \& Paranich, A.V. (2000). Vyznachennia vydovoho pokhodzhennia roslynnykh olii [Determination of the species origin of vegetable oils]. Farmatsevtychnyi zhurnal Pharmaceutical Journal, 5, 86-90 [in Ukrainian].

4. Yunusova, S.H., Yunusov, M.S., Karimova, A.R., Mironov, V.F., \& Minzanova, S.H. (2007). Lipidy semyan Oenothera $s$ razlichnykh mest proizrastaniya. Soobshcheniye [Oenothera seed lipids from different places of growth. Message I.]. Khimiya prirodnykh soyedineniy - Chemistry of Natural Compounds, 5, 430-433 [in Russian].
13. Исследование жирнокислотного состава травы золототысячника обыкновенного и травы чистеца Зибольда [Электронный ресурс] / Л. И. Стойко, Л. В. Гусак, С. М. Марчишин, О.Л.Демидяк // Медицина и образование в Сибири : сетевое научное издание. - 2015. - № 6. - Режим доступа : http:// ngmu.ru/cozo/mos/article/text_full.php?id=1957.

14. Marchyshyn S. M. The content of fatty acids in lipophilic extracts of Veronica chamaedrys L. and Veronica officinalis L. / S. M. Marchyshyn, I. I. Milian // Journal of Education, Health and Sport. - 2016. - 6, No. 3. P. 91-96.

15. Смойловська Г. П. Дослідження якісного складу та кількісного вмісту карбонових кислот у листі Urtica dioica L. / Г.П.Смойловська // Актуальні питання фрармацевтичної і медичної науки та практики. 2015. - № 3 (19). - С. 48-51.

16. Сиренко Ю. Н. Влияние омега-3 полиненасыщенных жирных кислот на фрункциональные свойства сосудов у больных артериальной гипертензией / Ю. Н. Сиренко, С. Н. Кушнир // Укр. мед. часоп. 2012. - № 4 (90). - С. 117-120.

17. Бережной В. В. Омега-3 полиненасыщенные жирные кислоты - важнейший вектор в сохранении здоровья детей и в коррекции вегетативных нарушений / В.В.Бережной, В.В.Корнеева // Современная педиатрия. - 2016. - № 7 (79). - С. 1-8.

18. Ching K. Chow. Fatty Acids in Foods and their Health Implications / Ching K. Chow. $-3^{\text {rd }}$ ed. - Boca Raton, London, New York: CRC Press, 2007. - 1296 p.

19. William H. Omega-3 fatty acids: the "Japanese" factor? / H. William // J. Am. Coll. Cardiol. - 2008. -52. P. 425-427.

5. Ling Tong, Lei Zhang, \& Shuanghui Yu (2007). Analysis of the fatty acids from Periploca sepium by GCMS and GC-FID. Asian Journal of Traditional Medicines, 2 (3), 110-114.

6. Hudz, N., \& Atamanchuk, T. (2015). Fitokhimichne doslidzhennia yakonu [Phytochemical examination of ankone]. XIKh Mizhnarodnyi medychnyi konhres studentiv i molodykh vchenykh, prysviachenyi pamiati rektora, chlena-korespondenta NAMN Ukrainy, profesora Leonida Yakymovycha Kovalchuka - XIX International Medical Congress of Students and Young Scientists, dedicated to the memory of Rector, Corresponding Member of the National Academy of Medical Sciences of Ukraine, Professor Leonid Yakymovych Kovalchuk. Ternopil: Ukrmedknyha [in Ukrainian].

7. Marchyshyn, S.M., \& Basaraba, R.lu. (2016). Vmist aminokyslot u travi kotiachykh lapok dvodomnykh (Antennaria dioica (L.) Gaertn.) [The content of amino acids in the grass of the cat's paws of two-edged (Antennaria dioica (L.) Gaertn.)]. Teoretychni ta praktychni aspekty doslidzhennia likarskykh roslyn: mat. II Mizhnarodnoi naukovo-praktychnoi internet-konferentsii - Theoretical and practical aspects of the study of medicinal plants: mat. II International scientific and practical internet-conference (Kharkiv, March 21-23). Kharkiv: NfaU [in Ukrainian]. 
8. Marchyshyn, S.M., Hudz, N.A., \& Mishchenko, L.T. (2017). Doslidzhennia fruktaniv yakona (POLYMNIA SONCHIFOLIUS POEPP. \& ENDL.) [The study of yakon fructans (POLYMNIA SONCHIFOLIUS POEPP. \& ENDL.)] Fitoterapiia. Chasopys - Phytotherapy. Journal, 3, 58-63 [in Ukrainian].

9. Marchyshyn, S., Hudz, N., Dakhym, I., Husak, L., \& Mishchenko, L. (2017). Analysis of phenolic compounds from Polymnia sonchifolia Poepp. et Endl. leaves by HPLC-method. The Pharma Innovation Journal, 6 (7), 980-983.

10. Marchyshyn, S., Basaraba, R., \& Berdey, T. (2017). Investigation of phenolic compounds of Antennaria dioica (L.) Gaertn. Herb. The Pharma Innovation Journal, 6 (8), 09-11.

11. Burlaka, I.S., \& Kyslychenko, V.S. (2011). Doslidzhennia lipofilnykh fraktsii travy kunychnyka zvychainoho ta shchuchnyka dernystoho [Investigation of the lipophilic fractions of grass of the cluster of ordinary and borage grasshopper]. Ukrainskyi medychnyi almanakh - Ukrainian Medical Almanac, 14 (2), 38-39 [in Ukrainian].

12. Mykhaliuk, O.B. (2013). Doslidzhennia lipofilnoi fraktsii lystkiv i plodiv lymonnyka kytaiskoho [Investigation of the lipophilic fraction of leaves and fruits of Chinese lemongrass]. Ukrainskyi biofarmatsevtychnyi zhurnal Ukrainian Biopharmaceutical Journal, 5, 45-49 [in Ukrainian].

13. Stoyko, L.I., Gusak, L.V., Marchyshyn, S.M., \& Demidyak, O.L. (2015). Issledovaniye zhyrnokislotnogo sostava travy zolototysyachnika obyknovennogo i travy chystetsa Zibolda [Investigation of the fatty acid composition of the grass of the golden thousandth of the common and the grass of the pure Sibold Elektronnyi resurs]. Meditsyna i obrazovaniye v Sibiri: setevoe nauchnoe izdanie - Medicine and Education in Siberia: Network Scientific Edition. - Retrieved from: http://ngmu.ru/cozo/mos/article/text_full.php?id=1957 [in Russian].

14. Marchyshyn, S.M., \& Milian, I.I. (2016). The content of fatty acids in lipophilic extracts of Veronica chamaedrys L. and Veronica officinalis. Journal of Education, Health and Sport, 6 (3), 91-96.

15. Smoilovska, H.P. (2015). Doslidzhennia yakisnoho skladu ta kilkisnoho vmistu karbonovykh kyslot u lysti Urtica dioica L. [Investigation of qualitative composition and quantitative content of carboxylic acids in Urtica dioica L.]. Aktualni pytannia farmatsevtychnoi i medychnoi nauky ta praktyky - Urgent Issues of Pharmaceutical and Medical Science and Practice, 3 (19), 48-51 [in Ukrainian].

16. Sirenko, Yu.N., \& Kushnir, S.N. (2012). Vliyanie omega-3 polinenasyshchennykh zhyrnykh kislot na funktsyonalnye svoystva sosudov $u$ bolnykh arterialnoy gipertenziyey [Influence of omega-3 polyunsaturated fatty acids on functional properties of blood vessels in patients with arterial hypertension]. Ukrainskyi med. Chasopys - Ukrainian Medical Journal, 4 (90), 117-120 [in Russian].

17. Berezhnoy V. V. Omega-3 polinenasyshchennye zhyrne kisloty - vazhneyshyy vektor v sokhranenii zdorovya detey i v korrektsyi vegetativnykh narusheniy [Omega-3 polyunsaturated fatty acids are the most important vector in preserving children's health and in correcting vegetative disorders]. Sovremennaya pediatriya - Modern Pediatrics, 7 (79), 1-8 [in Russian].

18. Ching, K. Chow (2007). Fatty acids in foods and their health implications. Boca Raton, London, New York: CRC Press.

19. William, H. (2008). Omega-3 fatty acids: the "Japanese" factor? J. Am. Coll Cardiol., 52, 425-427.

С. М. Марчишин, Н. А. Гудзь, Р. Ю. Басараба, Т. Я. Ярошенко ТЕРНОПОЛЬСКИЙ ГОСУДАРСТВЕННЫЙ МЕДИЦИНСКИЙ УНИВЕРСИТЕТ ИМЕНИ И. Я. ГОРБАЧЕВСКОГО

\section{ИССЛЕДОВАНИЕ ЖИРНОКИСЛОТНОГО СОСТАВА НЕКОТОРЫХ РАСТЕНИЙ CЕМЕЙСТВА АСТРОВЫЕ (ASTERACEAE)}

\section{Резюме}

Вступление. В последнее время большое внимание уделяют исследованию липофильных комплексов лекарственных растений, составной частью которых являются жирные кислоты, которые играют важную роль в жизнедеятельности организма человека. Растения семейства астровые (Asteraceae) якон (Smallanthus sonchifolius (Poepp. And Endl.) H. Robinson), стевия медоносная (Stevia rebaudiana (Bertoni) Hemsley) и кошачьи лапки дводомные (Antennaria dioica (L.) Gaertn.) - содержат комплекс биологически активных веществ, среди которых значительное место отводят липофильным компонентам (жирным кислотам, каротиноидам, хлорофриллам и т. д.).

В источниках научной литературы недостаточно информации о жирнокислотном составе исследуемых видов, поэтому целью наших исследований было изучить липофильные фрракции листьев стевии медоносной, корневых клубней и листьев якона, травы кошачьих лапок двудомных и определить содержание жирных кислот в их составе. 
Методы исследования. Липофильные фрракции исследуемых видов лекарственного растительного сырья получали путем исчерпывающего экстрагирования сырья хлорофрормом в аппарате Сокслета. Качественный состав и количественное содержание жирных кислот в исследуемом лекарственном растительном сырье определяли методом газожидкостной хромато-масс-спектрометрии метиловых эфриров жирных кислот на газовой хромато-масс-спектрометрической системе Agilent 6890N/5973inert (Agilent Technologies, США). Идентификацию метиловых эфриров жирных кислот исследуемой смеси проводили путем сравнения времени удерживания стандартной смеси метиловых эфиров жирных кислот (Supelco, США). Использовали библиотеку масс-спектров NIST 02.

Результаты и обсуждение. Липофильная фрракция, выделенная из корневых клубней якона, - густая маслянистая однородная масса буро-коричневого цвета с приятным специфическим запахом, не растворяется в воде и этаноле, хорошо растворяется в хлороформе. Липофрильные фрракции листьев темно-зеленого цвета; травы кошачьих лапок двудомных - светло-зеленого; по другим фризическим показателям полученные субстанции не отличались. Установлено, что выход липофильных веществ из листьев якона и листьев стевии медоносной был почти одинаков - $(9,55 \pm 0,09)$ и $(9,05 \pm 0,07) \%$, из корневых клубней якона - в 2,4 и 2,2 раза меньше, чем из листьев соответственно. Выход липофильных фрракций из травы кошачьих лапок двудомных составлял $(8,25 \pm 0,09) \%$. В липофильных экстрактах листьев якона и травы кошачьих лапок двудомных выявлено по 9 жирных кислот, 2 из которых являются полиненасыщенными - линолевая и линоленовая; в липофильном экстракте листьев стевии медоносной - 8 жирных кислот, из которых в наибольшем количестве представлена линоленовая кислота. В липофильных экстрактах листьев стевии медоносной и травы кошачьих лапок двудомных содержится насыщенная пальмитиновая кислота. Содержание ненасыщенных жирных кислот в исследуемых липофильных экстрактах преобладал над содержанием насыщенных. Их соотношение в листьях якона составляло 55,35:8,63; в листьях стевии медоносной - 3,04:1,87; в траве кошачьих лапок двудомных - 29,09:20,26 соответственно. В липофильном экстракте корневых клубней якона идентифицированы только линолевая и линоленовая кислоты.

Выводы. Впервые методом газожидкостной хромато-масс-спектрометрии определен жирнокислотный состав липофильных фрракций листьев стевии медоносной, корневых клубней и листьев якона и травы кошачьих лапок двудомных. В листьях стевии медоносной и якона и траве кошачьих лапок двудомных ненасыщенные жирные кислоты преобладают над насыщенными. В исследуемых объектах доминируют полиненасыщенные жирные кислоты - линолевая и линоленовая. В корневых клубнях якона идентифицированы только линолевая и линоленовая кислоты.

КЛЮЧЕВЫЕ СЛОВА: стевия медоносная; якон; кошачьи лапки двудомные; липофильные комплексы; жирные кислоты.

S. M. Marchyshyn, N. A. Hudz, R. Iu. Basaraba, T. Ya. Yaroshenko I. HORBACHEVSKY TERNOPIL STATE MEDICAL UNIVERSITY

\section{INVESTIGATION OF SOME ASTERACEAE PLANTS FATTY ACID COMPOSITION}

Introduction. Recently, much attention has been paid to the study of medicinal plants' lipophilic complexes, part of which is fatty acids, which play an important role in the life activities of a human body. The plants of the Asteraceae family - yacon (the Smallanhus sonchifolius (Poepp. and Endl.) H. Robinson), stevia rebaudiana (Bertoni) Hemsley and cat's paw (Antennaria dioica (L.) Gaertn.) contain the complex of biologically active substances, among which a significant place is given to lipophilic components (fatty acids, carotenoids, chlorophylls, etc.).

In the sources of scientific literature, there is not enough information about the studied species' fatty acid composition. Therefore, the aim of our research is to study the lipophilic fractions of stevia leaves, yacon root tubers and leaves, cat's paw herbs, and to determine the content of fatty acids in their composition.

Research Methods. Lipophilic fractions of the studied species are obtained by exhaustive extraction of raw materials with chloroform in the Soxhlet apparatus. Determination of qualitative composition and quantitative content of fatty acids in the investigated medicinal plant material is carried out by the gas-liquid chromatographic/mass spectrometric method of fatty acids methyl esters on the gas chromatographic/mass spectrometric system Agilent 6890 N/5973inert (Agilent Technologies, USA). The identification of fatty acid methyl esters in the test mixture is carried out by comparing the retention time of fatty acids methyl esters standard mixture (Supelco, USA). The NIST 02 mass spectrum library is used. 
Results and Discussion. The isolated lipophilic fraction from yacon root tubers - a thick oily homogeneous mass of brown colour with a pleasant specific odor; not soluble in water and ethanol, is readily soluble in chloroform. Lipophilic fractions of stevia leaves are of dark green colour; cat's paw herbs - light green colour; according to other physical indicators, the obtained substances do not differ. It is established that the yield of lipophilic substances from yacon and stevia leaves are almost the same - $(9.55 \pm 0.09) \%$ and $(9.05 \pm 0.07) \%$, from yacon roots - in 2.4 and 2.2 times smaller than leaves, respectively. The yield of the lipophilic fraction from cat's paw herbs is (8.25 \pm 0.09$) \% .9$ fatty acids are detected in the lipophilic extract of yacon leaves and cat's paw herbs, 2 of which are polyunsaturated (linoleic and linolenic). 8 fatty acids are detected in the lipophilic extract of stevia leaves, where linolenic acid is present in the largest number. The lipophilic extract of stevia leaves and cat's paw herbs contains the saturated palmitic acid. The content of unsaturated fatty acids in the studied lipophilic extracts predominates over saturated. Their ratio in yacon leaves is 55.35:8.63; stevia leaves - 3.04:1.87; cat's paw herbs - 29.09:20.26, respectively. Only the linoleic and linolenic acids are identified in the lipophilic extract of yacon root tubers.

Conclusions. The fatty acid composition of the lipophilic fractions of stevia leaves, yacon root tubers and leaves, and cat's paw herbs is determined by the gas-liquid chromatographic/mass spectrometric method for the first time. The content of unsaturated fatty acids in stevia and yacon leaves, and cat's paw herbs predominates over saturated. Polyunsaturated fatty acids (linoleic and linolenic) are dominant in the investigated objects. Only the linoleic and linolenic acids are identified in yacon root tubers.

KEY WORDS: stevia rebaudiana (Bertoni) Hemsley; yacon; cat's paw, lipophilic complexes; fatty acids.

Отримано 25.01.18

Адреса для листування: С. М. Марчишин, Тернопільський державний медичний університет імені І. Я. Горбачевського, майдан волі, 1, Тернопіль, 46001, Україна, e-mail: marchyshyn@tdmu.edu.ua. 